\title{
Paleoindian to Middle Archaic Projectile Points from East Texas
}

Timothy K. Perttula

Heritage Research Center, Stephen F. Austin State University

Follow this and additional works at: https://scholarworks.sfasu.edu/ita

Part of the American Material Culture Commons, Archaeological Anthropology Commons, Environmental Studies Commons, Other American Studies Commons, Other Arts and Humanities Commons, Other History of Art, Architecture, and Archaeology Commons, and the United States History Commons

Tell us how this article helped you.

This Article is brought to you for free and open access by the Center for Regional Heritage Research at SFA ScholarWorks. It has been accepted for inclusion in Index of Texas Archaeology: Open Access Gray Literature from the Lone Star State by an authorized editor of SFA ScholarWorks. For more information, please contact cdsscholarworks@sfasu.edu. 


\section{Paleoindian to Middle Archaic Projectile Points from East Texas}

Creative Commons License

(c) (i) (8)

This work is licensed under a Creative Commons Attribution-NonCommercial 4.0 International License 


\title{
Paleoindian to Middle Archaic Projectile Points from East Texas
}

\author{
Timothy K. Perttula
}

\section{INTRODUCTION}

This article discusses and describes a number of distinctive Paleoindian to Middle Archaic projectile points from East Texas, centering on the middle Sabine River basin (Figure 1) and the collecting areas roamed by Buddy Calvin Jones. It is likely that these points were collected in the 1950s and 1960s from the surface at a series of sites in the Sabine River valley (Patti Haskins, February 2013 e-mail communication).

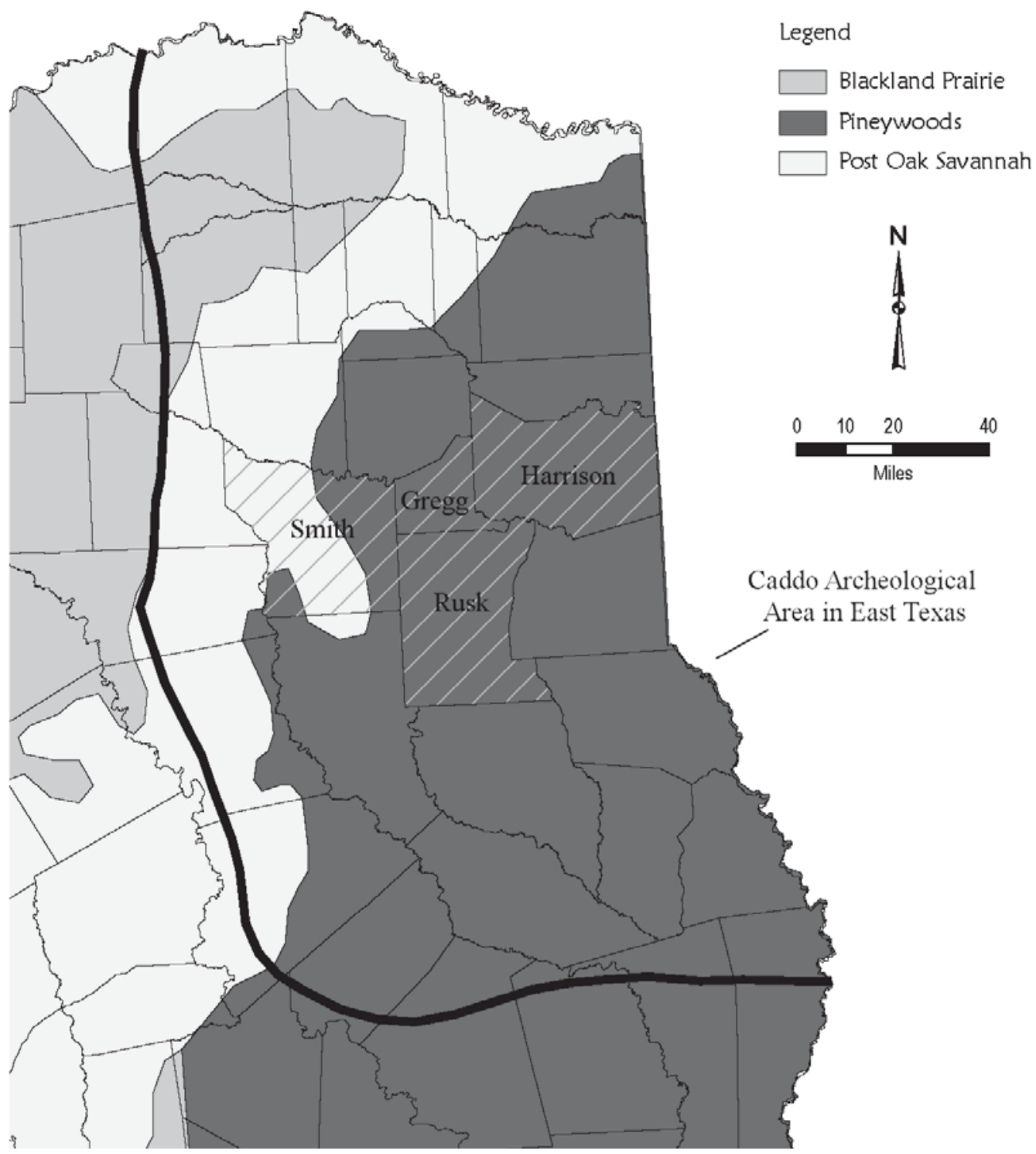

Figure 1. East Texas collecting area by Buddy Calvin Jones. 


\section{CONTEXT}

For the purposes of this article, the Paleoindian period in East Texas dates prior to 10,000 years B.P., perhaps beginning as long as 11,500 years B.P. or older, depending upon the age of any pre-Clovis era sites in the larger region. The Archaic period in East Texas lasts from 10,000 years B.P. to approximately 2500 years B.P., with the Early Archaic dating from ca. 10,000-8000 years B.P. (8050-6050 B.C.), the Middle Archaic ranging from 8000-5000 years B.P. (6050-3050 B.C.), and the Late Archaic dating from 5000-2500 years B.P. (3050-550 B.C.). The chronological ages and dates in this article are the uncalibrated calendar ages in years B.P.

The temporal ordering of Paleoindian and Archaic projectile points in East Texas draws upon the few available absolute dates from East Texas on Archaic sites, as well as the known temporal sequences of projectile points in surrounding regions, such as Southwest Arkansas (Schambach 1998; Trubitt 2009), Northwest and Northern Louisiana (Girard 2000; Girard et al. 2011; Anderson and Smith 2003; Rees 2010; Saunders 2010), the Missouri Ozarks (Ray et al. 2009), and Central Texas (Bousman and Oksanen 2012; Collins 1998; Collins et al. 2011; see also Turner et al. 2011), typically supported with series of radiocarbon dates from features and buried archaeological deposits. The age of the earliest well-established Paleoindian projectile point, the Clovis type, has been refined by Waters and Stafford (2007; see also Waters et al. 2011). This provisional ordering of projectile points also relied upon a recent cladistics study (see O'Brien and Lyman [2003] and Lipo et al. [2006] for considerations of cladistics and archaeological studies) of 93 Texas dart point types that has plotted the statistical affinities among the various types (Carpenter and Paquin 2010:158 and Figures 2 and 3). From these relationships, Carpenter and Paquin (2010:Figure 4) proposed hypothetical relationships between dart point types "based on overlap in temporal, spatial, and formal attributes."

In creating Figure 2, then, beginning in the Late Paleoindian period at ca. 10,500 years B.P., I employed the hypothetical relationships between types detected in the Carpenter and Paquin (2010) cladistics study, focusing only on those dart point types known to have been made and used at various times in the East Texas Paleoindian and Archaic (even if they were not included in Carpenter and Paquin [2010]), regardless of whether the spatial distributions of certain points (i.e., Evans, Pontchartrain, Epps, Rice Lobed, or Jakie Stemmed) suggested some types were common in the archeological record in one or more surrounding states. Known temporal ages of these additional project point types were used to place them in their best approximate age on Figure 2.

Based on these various lines of evidence, as well as the earlier suggested chronological sequences for East Texas dart points proposed by Story (1990:Figure 32) and Thurmond (1990:Table 8), the Paleoindian dart point sequence begins with the Clovis point (ca. 11,500 years B.P.), while the Early Archaic dart point sequence begins with Dalton and San Patrice points, although both point types were first made sometime prior to 10,000 years B.P. (Koldehoff and Walthall 2009: Ray et al. 2009) and are often considered to also be diagnostic of the Late Paleoindian period in the broader region. Recent radiocarbon dates from the Big Eddy site in southwest Missouri indicates both points were made and used until ca. 9800 years B.P. (Ray et al. 2009:160), in the early years of the Late Paleoindian-Early Archaic technological, subsistence, and settlement/mobility transition (cf. Bousman et al. 2002:989; Bousman and Oksanen 2012). Later Early Archaic points (ca. 9800-9000 years B.P.) include the Breckenridge, Scottsbluff, and Keithville types (Webb 2000:4), as well as later Pelican, Graham Cave, and Rice Lobed points (ca. 8500-8000 years B.P.).

Proposed early Middle Archaic points in East Texas include the Hidden Valley and Kirk types, as well as the Palmer type, although these are points that are not particularly common in East Texas dart point assemblages (e.g., Jones 1957; Rogers and Perttula 2004; Furman and Amick 2006; Turner 2006:Table 7). Between 6500-5000 years B.P., Middle Archaic points are suggested to include the Cossatot, Johnson, Jakie Stemmed, White River side-notched points (sometimes referred to as Big Sandy points, see Ray and Lopinot 2003), Morrill, Bell and Andice (or Calf Creek), and the distinctive blade-notched Evans point (see Figure 2). 
Years before present

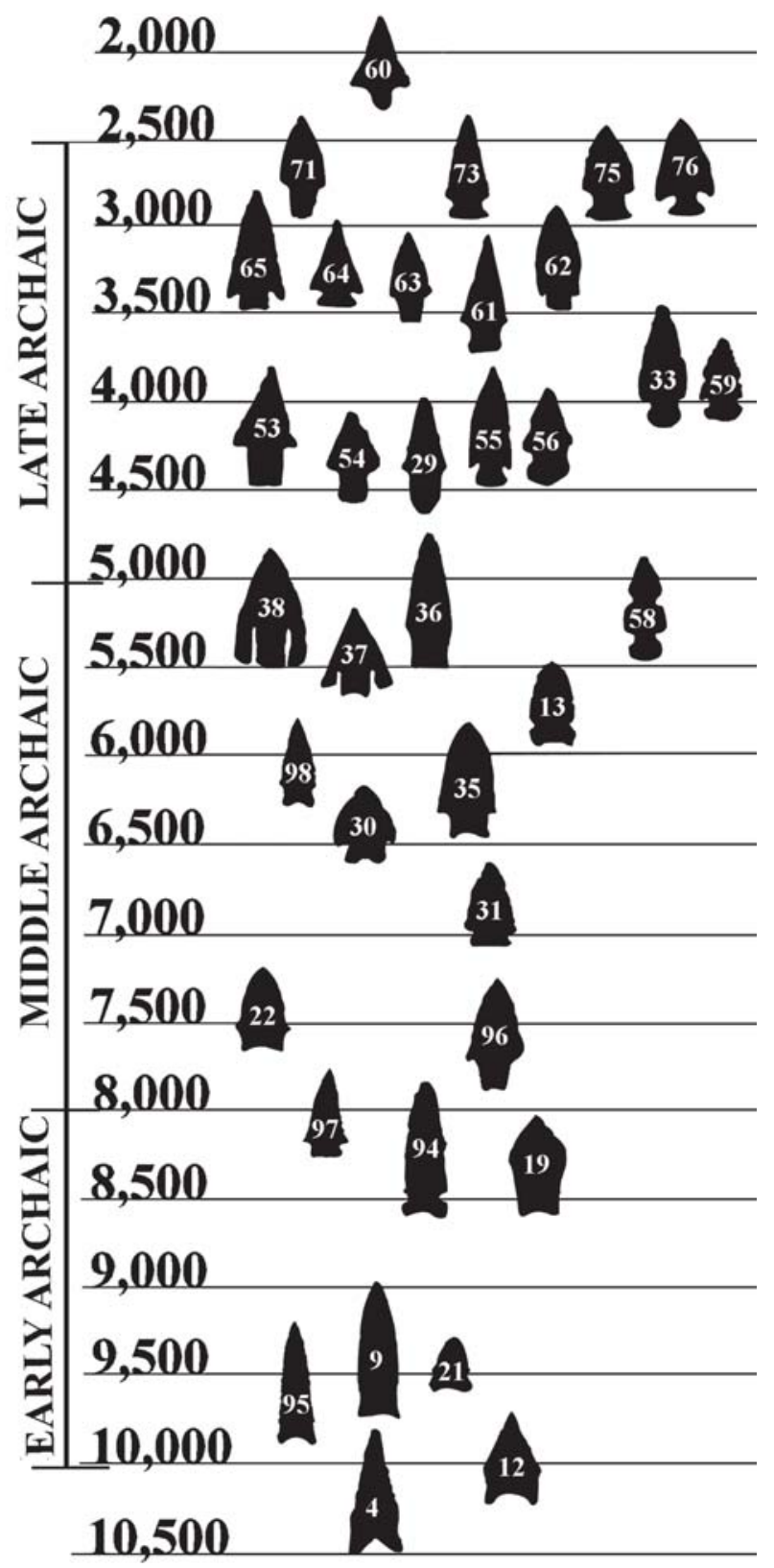

Figure 2. Proposed temporal ordering of dart points in the East Texas Archaic, ca. 10,000-2500 years B.P. (after Carpenter and Paquin 2010). Key to Projectile Point Types on Figure 2: 4. Dalton; 9. Scottsbluff; 12. San Patrice; 13. White River; 19. Pelican; 21. Keithville; 22. Kirk; 29. Wells; 30. Cossatot; 31. Palmer; 33. Palmillas; 35. Johnson; 36. Morrill; 37. Bell; 38. Andice; 53. Bulverde; 54. Carrollton; 55. Williams; 56. Trinity; 58. Evans; 59. Neches River; 60. Gary; 61. Yarbrough; 62. Pontchartrain; 63. Kent; 64. Ellis; 65. Marshall; 71. Dawson; 73. Godley; 75. Epps; 76. Motley; 94. Graham Cave; 95. Breckenridge; 96. Hidden Valley; 97. Rice Lobed; 98. Jakie. Figure drawn by Lance Trask, based in part on Carpenter and Paquin (2010).

\section{POINT TYPES}

This sample $(n=41)$ of Paleoindian to Middle Archaic projectile points in the Buddy Jones collection includes examples from 10 different defined projectile point types, that have been found on sites in the region that have dated occupations that span the interval from ca. 11,500 years B.P. to 6000 years B.P. The most abundant projectile point is the Dalton type $(n=8)$, found on sites in eastern and east central Texas (Bousman and Oksanen 2012:Figure 9.20), the Trans-Mississippi South, including the Ozarks (Kay 2012), and much of the Mississippi River valley (Koldehoff and Walthall 2009:Figure $6.1)$, and side-notched Keithville points $(n=4)$; Anderson and Smith (2003:Figure 5.10) and Rees (2010:Figure 3.1) refer to them as San Patrice, var. Keithville. These points occur in association with San Patrice points (Webb et al. 1971). There are also many $(n=12)$ unidentified lanceolate basal fragments in the point sample.

\section{Clovis}

The three Clovis points are made from cherts that are not local to East Texas. This includes a gray chert (Figure 3a), possibly from a Central Texas Edwards Formation source (see Waters et al. 2011:Figure 99), a lustrous gray chert with reddish-brown inclusions (Figure 4b), also possibly from a Central Texas source, and a dark gray chert (Figure 3b) that may have its source in the Johns Valley Formation in the Ouachita Mountains of Southeast Oklahoma (see Banks 1990); this material may also be found in Red River gravels. These points date from cal 13,100-12,800 years B.P. (Waters and Stafford 2007), and they are found on sites and localities across almost all parts of Texas, including East Texas (Bousman and Oksanen 2012:Figure 9.16).

The Clovis points have lateral and basal grinding and concave bases (Table 1), with flute scars on both faces. The flute scars range from $12-23 \mathrm{~mm}$ in length and 10-15 $\mathrm{mm}$ in width. Two of the three points have resharpened blades. 


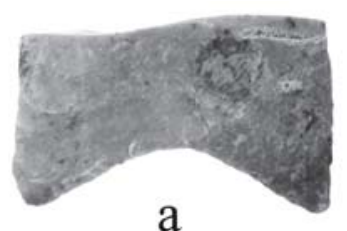

a

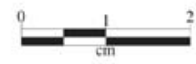

Figure 3. Clovis points: a, No. 1; b, No. 2003.08.162.

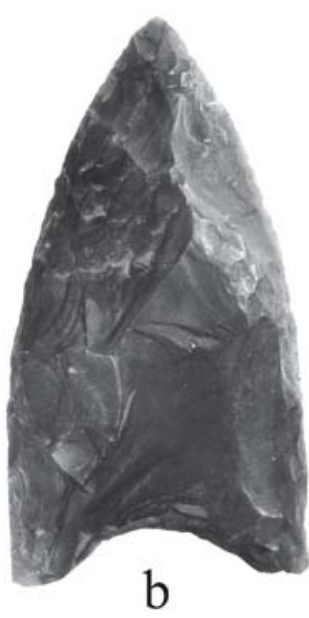

b

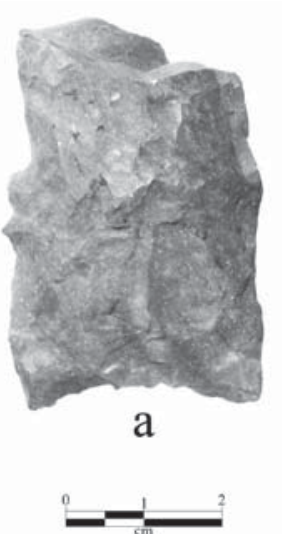

Figure 4. Unidentified lanceolate point and a Clovis point: a, unidentified lanceolate (No. 14); b, Clovis (No. 2003.08.161).

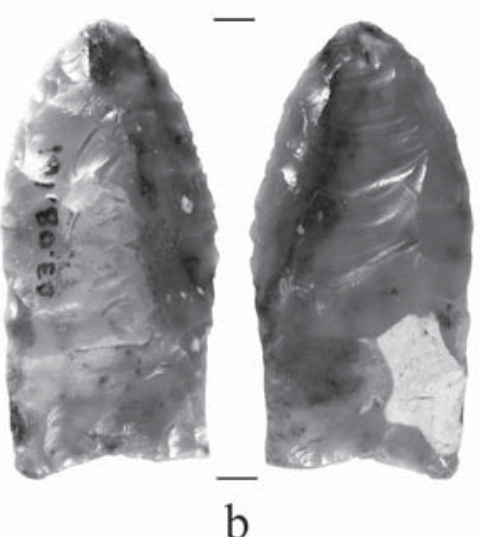

b
. 
Table 1. Projectile Point Attributes, cont.

\begin{tabular}{|c|c|c|c|c|c|c|c|c|c|}
\hline No. & Type & $\mathrm{RM}$ & $\begin{array}{l}\mathrm{L} \\
(\mathrm{mm})\end{array}$ & $\begin{array}{l}\mathrm{W} \\
(\mathrm{mm})\end{array}$ & $\begin{array}{l}\text { Th } \\
(\mathrm{mm})\end{array}$ & $\begin{array}{l}\mathrm{SW} \\
(\mathrm{mm})\end{array}$ & $\begin{array}{l}\text { Base } \\
\text { Shape }\end{array}$ & GR & $\mathrm{RS}$ \\
\hline 22 & $\begin{array}{l}\text { Scottsbluff, } \\
\text { Red River knife }\end{array}$ & br chert & 41.5 & 24.2 & 6.6 & 21.1 & $\begin{array}{l}\text { straight- } \\
\text { concave }\end{array}$ & ba & +/beveled \\
\hline 2 & UID lanceolate & w chert & - & 25.8 & 5.6 & - & concave & lt & $?$ \\
\hline 3 & UID lanceolate & g-y chert & - & 28.6 & 6.3 & - & concave & $1 \mathrm{t} / \mathrm{ba}$ & ? \\
\hline 4 & UID lanceolate & $\lg \mathrm{NOV}$ & - & 23.3 & 7.1 & - & concave & lt/ba & $?$ \\
\hline \multirow[t]{2}{*}{6} & UID lanceolate & banded & - & 29.9 & 6.9 & - & concave & $1 \mathrm{t} / \mathrm{ba}$ & $?$ \\
\hline & & chert & g-br-lg & & & & & & \\
\hline 7 & UID lanceolate & w NOV & - & 23.0 & 6.0 & - & concave & $1 \mathrm{t} / \mathrm{ba}$ & $?$ \\
\hline 9 & UID lanceolate & $\lg$ chert & - & 32.1 & 6.2 & - & concave & lt & $?$ \\
\hline 10 & UID lanceolate & dg chert & - & 28.9 & 4.7 & - & straight & - & $?$ \\
\hline 11 & UID lanceolate & dg QTZ & - & 26.7 & 5.0 & - & concave & ba & $?$ \\
\hline 18 & UID lanceolate & g-dg & $\begin{array}{l}- \\
\text { chert }\end{array}$ & 27.8 & 6.0 & - & concave & ba & $?$ \\
\hline $18 \mathrm{~B}$ & $\begin{array}{l}\text { UID lanceolate } \\
\text { preform }\end{array}$ & $\mathrm{g}$ chert & - & 25.4 & 6.7 & - & concave & - & $?$ \\
\hline 19 & UID lanceolate & $\mathrm{g}$ chert & - & 19.3 & 5.1 & - & concave & $1 \mathrm{t} / \mathrm{ba}$ & $?$ \\
\hline 14 & $\begin{array}{l}\text { UID lanceolate } \\
\text { (cf. Scottsbluff) }\end{array}$ & dg chert & - & 29.0 & 11.2 & - & concave & lt & $?$ \\
\hline 12 & Pelican & g chert & - & 24.0 & 8.1 & - & concave & la & $?$ \\
\hline 29 & Palmer & PW & 27.3 & 22.0 & 6.1 & 16.1 & concave & - & + \\
\hline $1 \mathrm{~B}$ & Johnson & g NOV & 19.8 & 26.8 & 7.0 & 21.0 & concave & - & + \\
\hline 15B & Johnson & br chert & 27.1 & 20.9 & 6.1 & 13.0 & concave & ba & + \\
\hline $16 \mathrm{~B}$ & Johnson & y NOV & 28.9 & 20.9 & 8.7 & 17.5 & concave & - & + \\
\hline $4 B$ & Jakie & br jasper & 15.1 & 24.3 & 6.6 & 15.9 & concave & - & + \\
\hline $5 \mathrm{~B}$ & Jakie & br jasper & 24.0 & 19.0 & 6.9 & 16.0 & concave & ba & + \\
\hline $8 B$ & Jakie & $\begin{array}{l}\text { dgb } \\
\text { chert }\end{array}$ & 16.9 & $19.2+$ & 5.5 & 12.4 & concave & - & + \\
\hline $2 \mathrm{~B}$ & White River & br chert & 19.9 & 27.0 & 7.5 & 18.2 & straight & - & + \\
\hline $3 \mathrm{~B}$ & White River & br jasper & 21.9 & 23.9 & 5.4 & 16.6 & straight & - & + \\
\hline $13 \mathrm{~B}$ & White River & bl chert & 15.7 & 24.7 & 7.8 & 18.0 & straight & ba & + \\
\hline
\end{tabular}

No.: Gregg County Historical Museum number; UID=unidentified; RM=raw material; $\mathrm{cg}=$ coarse-grained; $\mathrm{r}=\mathrm{red}$; $\mathrm{w}=$ white; $\mathrm{g}=$ gray; $\mathrm{y}=\mathrm{yellow}$; $\mathrm{dg}=$ dark gray; $\mathrm{dg} b=$ dark grayish-brown; lg=light gray; bl=black; blu=blue; br=brown; NOV=novaculite; $\mathrm{QTZ}=$ quartzite; PW=petrified wood; L=length; W=width; $\mathrm{Th}=$ thickness; $\mathrm{SW}=$ =stem width; GR=grinding; lt=lateral; ba=basal; RS=resharpened; +=present; -=absent; ?=unknown 


\section{Dalton}

There are eight Dalton lanceolate points in this sample of points (see Table 1). They have concave bases, with lateral and/or basal grinding, basal ears, and extensive blade resharpening and/ or beveling (Figures 5-6, 7a; see also Figure 10j, below). One of the examples has very pronounced ears and shoulders (Figure 7a), similar to what has been named the Breckenridge Dalton (Kay 2012:Figure 10.3).

Six of the Dalton points are made from chert, primarily a gray chert, but one point is made from a dark grayish-blue chert of unknown source area (see Figure 5b); both kinds of cherts are non-local resources in East Texas. Two other Dalton points (see Figure 5a and Figure 6a) are made from a coarse-grained light gray quartzite that closely resembles a quartzite found in the Glover Sandstone Formation in the Neches River basin in East Texas (Perttula and Nelson 2006). Dalton points occur widely in East Texas and in the Trinity, upper Brazos, and Colorado River basin in East Central and Central Texas (Bousman and Oksanen 2012:Figure 9.20). Dalton and San Patrice points are generally considered contemporaneous in sites on the Southern Plains and in the Trans-Mississippi South, dating from ca. 10,500-9800 years B.P. (Ray et al. 2009; Bousman and Oksanen 2012), at the end of the Late Paleoindian period and the beginning of the Early Archaic period.

\section{San Patrice}

The two probable San Patrice points in this collection resemble the var. St. Johns defined by Webb et al. (1971:13-14 and Figure 4). They have concave bases, one is basally ground, and both have resharpened blades (Figure $7 b-c)$. One of the points is made from a red jasper (Figure $7 b$ ), while the other is made from a light gray chert (Figure 7c).

San Patrice points date from ca. 10,500-9800 years B.P., at the end of the Paleoindian period and the beginning of the early Archaic period (Ray et al. 2009; Bousman and Oksanen 2012), broadly contemporaneous with the Dalton lanceolate points. They occur widely across East Texas (Bousman and Oksanen 2012:Figure 9.19). At Horn Shelter, San Patrice and Scottsbluff points were found in layer 5F to layer 7 (Bousman and

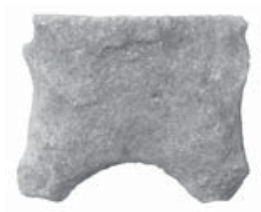

a

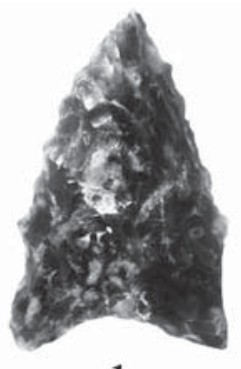

b
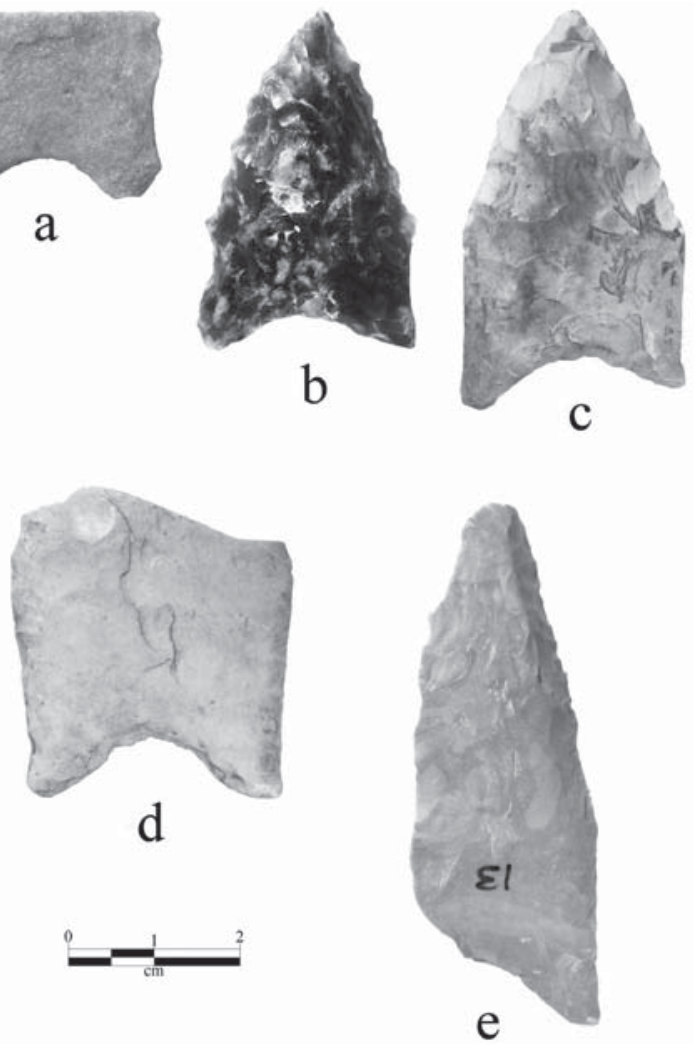

Figure 5. Dalton points: a, No. 16; b, No. 20; c, No. 17; d, No. 5; e, No. 13.

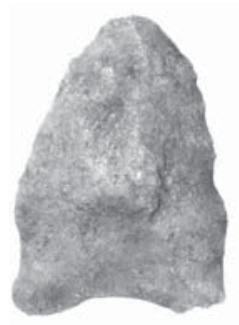

a
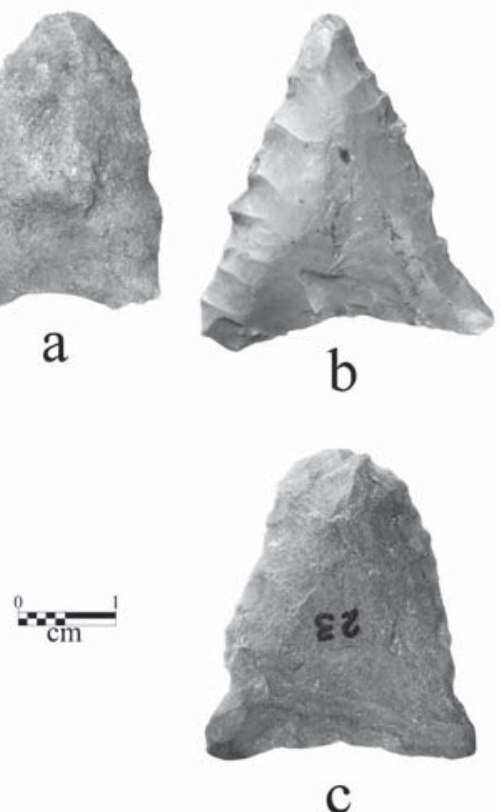

C

Figure 6. Dalton and Keithville points: a, Dalton (No. 15); b, Keithville (No. 21); c, Keithville (No. 23). 


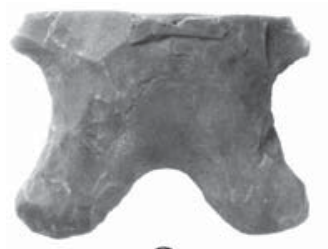

a

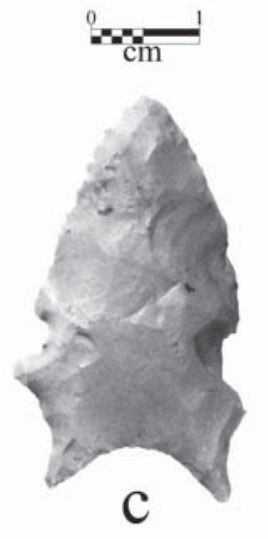

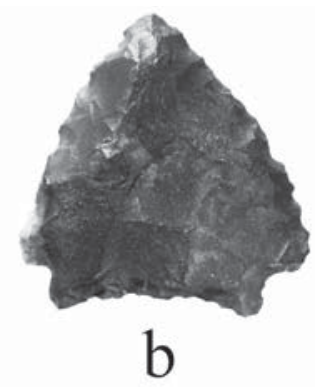

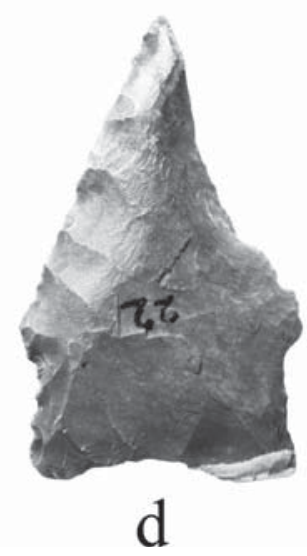

Figure 7. Dalton, San Patrice, and Scottsbluff points: a, Dalton (No. 25); b, San Patrice, var. St. Johns (No. 26); c, cf. San Patrice, var. St. Johns (No. 24); d, Scottsbluff/Red River Knife (No. 22).
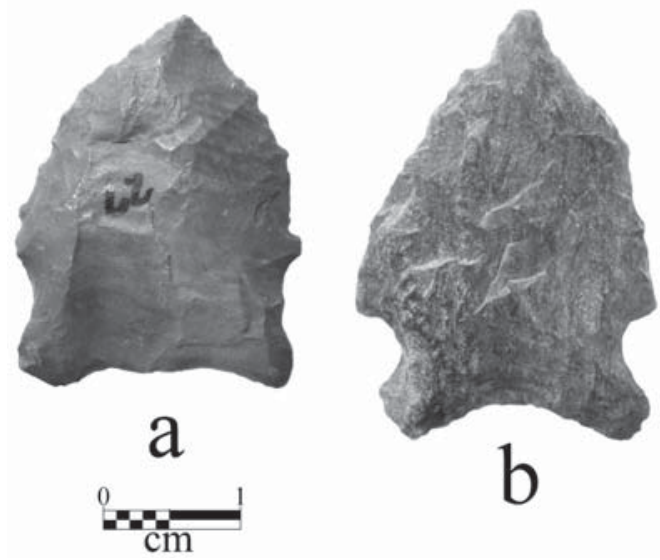

Figure 8 . Keithville points: a, No. 27; b, No. 28 .
Oksanen 2012:Figure 9.4); layer 5G has an uncalibrated radiocarbon age range of 9980-9500 years B.P. (Bousman and Oksanen 2012:204).

San Patrice projectile points and associated tools are typically manufactured on local raw materials (Saunders and Allen 1997:3; Webb et al. 1971), at least in sites thought to be situated in the woodlands (See Jennings 2008a, 2008b). In plains San Patrice sites, about 21\% of the San Patrice points are made from exotic raw material sources compared to only $6 \%$ of the San Patrice points from woodland contexts (Jennings 2008a:Table 7). There is a marked preference for the use of non-local lithic raw materials in other Late Paleoindian-Early Archaic chipped stone tools.

\section{Keithville}

The four Keithville, or San Patrice, var. Keithville points have shallow side notches, concave bases with basal grinding, and resharpened and serrated blades (Figure 8a-b, see also Figure 6b-c and Table 1). One of the points has a bifacial scraper edge along its resharpened blade (see Figure 6c). The points are made from local lithic raw materials, including petrified wood, a brown chert, and a brownish-yellow chert, as well as a brown jasper (Figure 8a), found in Red River gravel sources.

Keithville points are associated with San Patrice points (see Webb et al. 1971:Figure 6). As such, they are considered Late Paleoindian-Early Archaic (ca. 10,5009800 years B.P., Ray et al. 2009; Bousman and Oksanen 2012) diagnostic chipped stone tools.

\section{Scottsbluff}

One brown chert lanceolate point is a Late Paleoindian Scottsbluff (see Figure 7d). It has been unifacially resharpened and beveled, and conforms in form and apparent function (i.e., cutting, scraping and sawing, Turner et al. 2011:160) to the Red River knife defined by Johnson (1989). The point has a straight stem and a concave base, with basal grinding (see Table 1).

\section{Late Paleoindian lanceolates}

There are 12 Late Paleoindian lanceolate point fragments (ca. 10,500-10,000 years B.P.) in this sample of points from the Buddy Jones collection (Figures 9a-b and 10a-i); one of these is a preform (Figure 10i). These lanceolate point fragments have concave and thinned (but not fluted) bases as well as lateral and/ or basal grinding (see Table 1). These points may be fragments from completed Dalton, Meserve, and/or Golondrina points, but these basal fragments also resemble lanceolates from the Scottsbluff site (Knudson 2013:Figure 11.4c) as well as Plainview points (Knudson 2002:Figure 7.12). 
The lanceolate point fragments are made primarily from a variety of non-local cherts $(n=9)$, ranging in color from white, to gray, to dark gray, probably from Central Texas and Ouachita Mountains source areas. There are also lanceolate point fragments that are dark greenish-gray Southeast Oklahoma Ouachita Mountains quartzite ( $\mathrm{n}=1$, see Figure 9a) and white (see Figure 10b) and light gray (see Figure 10c) Ouachita Mountains novaculite.

One unidentified lanceolate point (see Figure 4a) may be a fragment of a Scottsbluff point as it has a broad and square and relatively thick stem, slightly concave, with lateral grinding (see Table 1). The point was broken by an impact fracture. It is made from a non-local dark gray chert with white flecks.

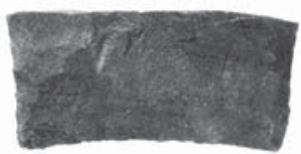

a

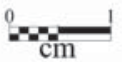

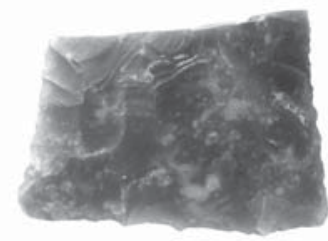

b
Figure 9. Late Paleoindian lanceolate point fragments: a, No. 11; b, No. 10.

\section{Pelican}

A broad and expanding lanceolate base fragment is identified as a Pelican point (Figure 11). The base is slightly concave, with lateral grinding (see Table 1). The point is made from a non-local gray chert probably from a Central Texas source area. Anderson and Smith (2003:277278) suggest that the Pelican point is a Late Paleoindian form dating from ca. 10,800-10,000 years B.P., related to and/or found in association with San Patrice (see Webb et al. 1971:Figure 7a-b) and Dalton points.

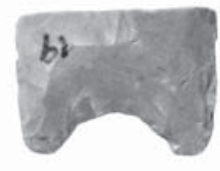

a

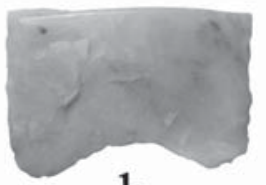

b

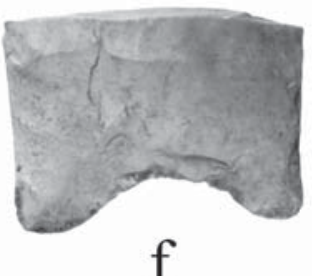

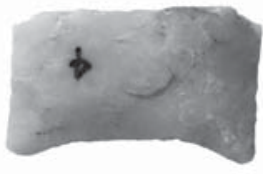

C

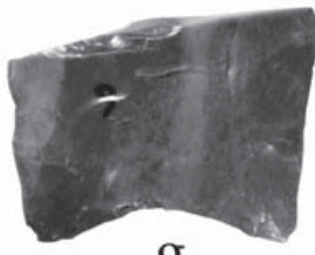

$\mathrm{g}$

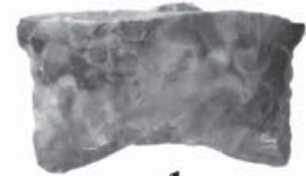

d

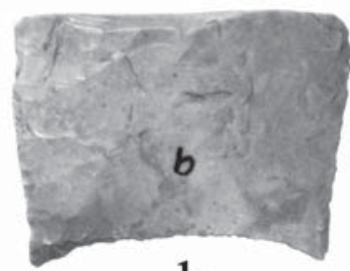

h

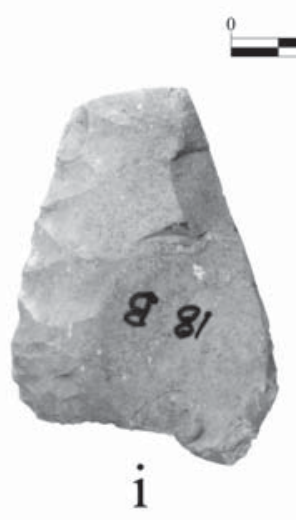

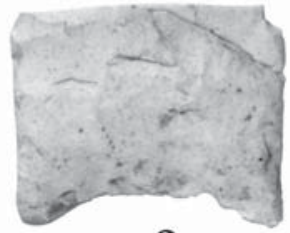

e
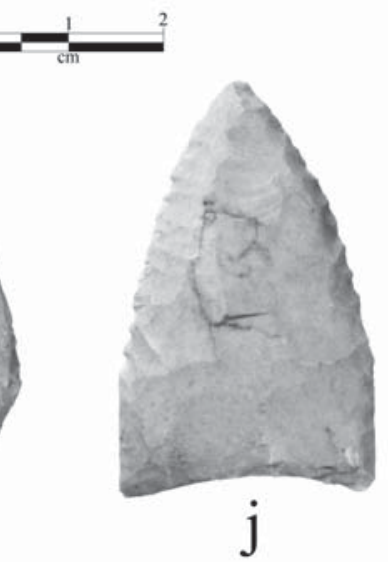

Figure 10. More Late Paleoindian lanceolate point fragments and a Dalton point: a, No. 19; b, No. 7; c, No. 4; d, No. 18; e, No. 2; f, No. 3; g, No. 6; h, No. 9; i, No. 18B (preform); and j, Dalton (No. 8). 


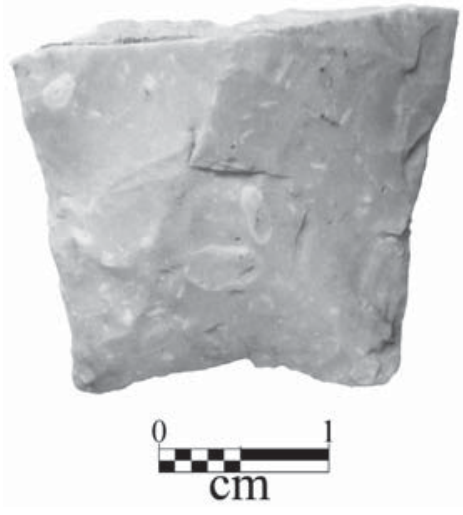

Figure 11. Pelican projectile point (No. 12).

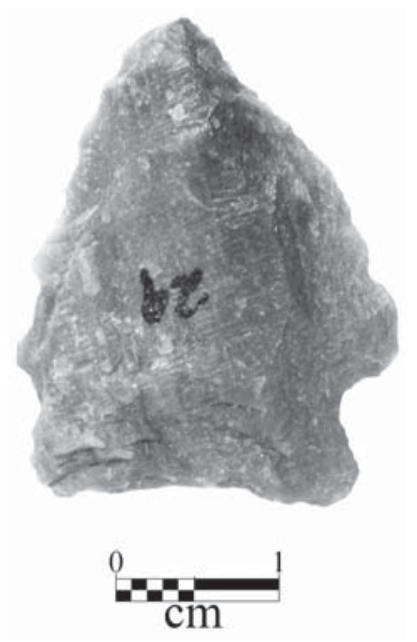

Figure 12. Palmer point (No. 29). collection are made from Ouachita Mountains novaculite, either gray (Figure 14a) or yellow (Figure 14c). The other Johnson point is made from a local brown chert (Figure 14b). These Johnson points have broad but short stems, concave bases, and short barbs (if they have not been removed through resharpening), and the blades have been resharpened into unifacial (Figure 14c) or bifacial scraper edges (Figure 14a-b) (see Table 1).

Trubitt (2009:78 and Table 4) reports that Johnson points in Southwest Arkansas and Northwest Louisiana have been recovered in components that may date from ca. 7140-6640 years B.P. (or 8050-7450 cal. years B.P.) This includes radiocarbon dates from the Conly site in Northwest Louisiana that range from $7140 \pm 160$ and $6650 \pm 40$ years B.P.; two possible Johnson points made from novaculite were found at the site (Girard et al. 2011). An OCR date of $7039 \pm 211$ B.P. from 3MN496 has also been obtained from a soil associated with a Johnson point (Trubitt 2009:78).

\section{Johnson}

Two of the three

\section{Palmer} include Palmer and Kirk Corner-Notched together as basically the same type, and they place the forms in an early corner-notched horizon that dates from 9500-8000 years B.P., in the Early Archaic. Bousman and Oksanen (2012:Figure 9.5) provide calibrated dates on Kirk points from Dust Cave, with two different summed probability distributions (calculated using OxCal 4.1.7) that range from ca. 10,200-9800 calibrated years B.P. and $8000-7600$ calibrated years B.P.

The Palmer point has shallow corner notches and small barbs, and

The three Jakie points, corner-notched with an expanding stem and shallow concave bases, are made from raw materials whose sources lie in the Ouachita Mountains in Southeast Oklahoma and that are also found in stream gravels along the Red River: a dark grayish-brown chert probably from the Johns Valley Formation (Figure 13a) and brown jasper (Figure $13 \mathrm{~b}-\mathrm{c})$. Each of the three points has a blade that has been extensively resharpened into a unifacial scraper edge (see Table 1).

Ray et al. (2009:172-173) suggest that the Jakie point dates to the early part of the Middle Archaic period (in the western Ozark Highlands), from ca. 8000-7000 years B.P.

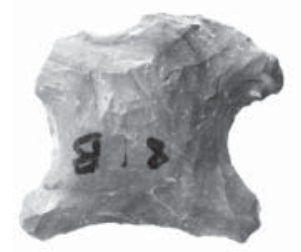

a

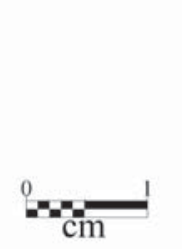

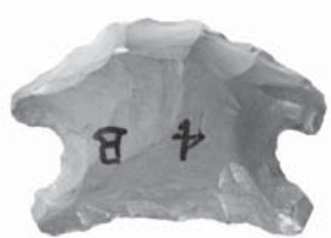

b

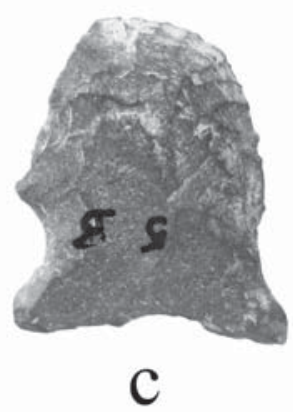

Figure 13. Jakie points: a, No. 8B; b, No. 4B; c, No. 5B. 


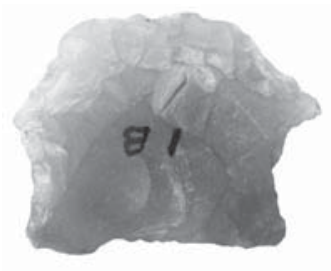

a

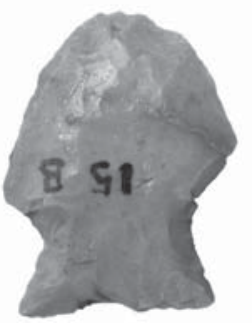

b
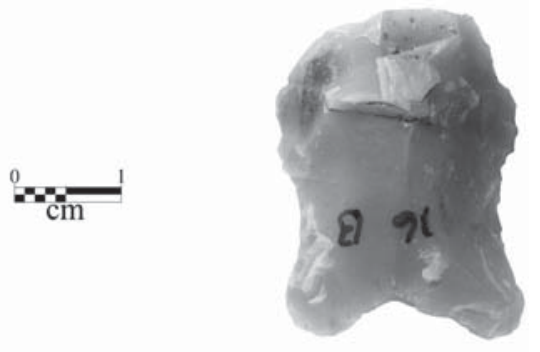

C

Figure 14. Johnson points: a, No. 1B; b, No. 15B; c, No. 16B.

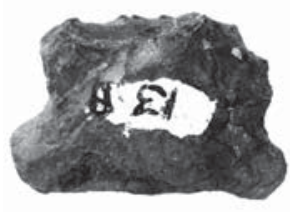

a

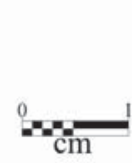

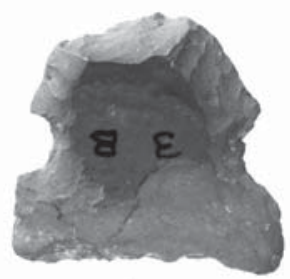

b

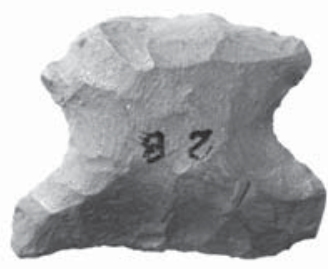

C

Figure 15. White River points: a, No. 13B; b, No. 3B; c, No. 2B. of the early Archaic archaeological remains (Plainview and Scottsbluff projectile points, and Cody knives) from the region are a result of Plains Early Archaic (ca. 10,000-9,000 years ago) groups that moved into 
parts of East Texas, during periods when grassland habitat spread eastward, to exploit the plains resources (such as bison) found there. However, the wide distribution of Scottsbluff projectile points in East Texas (see Bousman and Oksanen 2012:Figure 9.19) and adjoining parts of the Trans-Mississippi South cast doubt on the Plains origins of the aboriginal peoples that made this style of lanceolate point.

Much of the period between ca. 8000-5000 years ago was drier than today (Bousman and Oksanen 2012:Figure 9.2), with apparent rapid and punctuated reductions in biomass as well as the local expansion of prairie habitats along the western margins of the region. Nevertheless, drier conditions and changing vegetation conditions did not preclude occupations during these periods. While the archaeological data are still rather limited in the Middle Archaic, it appears that group mobility remained high for these huntinggathering foragers (who utilized hardwood nuts, deer, shellfish, turtles, and small mammals) during the Middle Archaic. At the Conley site (16BI19) in northwestern Louisiana, a cal. 7100-8300 year old occupation, the Middle Archaic groups there "focused on deer and slack water aquatic species, but a wide range of resources, from varied microenvironments, was exploited" (Girard 2000:63; see also Girard et al. 2011). Hickory nuts and acorns were also common in the archaeological deposits.

Group territories were large and poorly defined, with most sites the product of repeated and recurrent occupations by small groups. Anderson (1996a) suggests that such Middle Archaic groups had highly mobile foraging adaptations along the Red River, the central Sabine River, and in interior uplands away from major drainages, with expedient lithic technologies. Most sites of this age were briefly used, but tended to concentrate in the larger drainages within the region. Sometime during the Middle Archaic period, fairly substantial and extensive occupations are recognized within the major basins in the region, with a rather limited use of smaller tributaries and headwater areas. Components of this period are open camps dominated by hunting tools and generalized cutting/scraping tools, debris, ground stone tools, and cores.

Burned rock features (possible hearths, ovens, and cooking pits?) and burned rock concentrations are present in dated late Middle Archaic contexts at a few sites in the Sulphur River drainage, suggesting that an important activity was the cooking and processing of plant foods, but mainly by small groups for short-term use (Fields et al. 1997:90). A single burned rock feature at the Unionville site (41CS151) has a calibrated age range of 6217-5924 B.P., during the latter part of the Middle Archaic period (Cliff et al. 1996).

Mound complexes of late Middle Archaic age in northern Louisiana at this time also suggest the development of more complex hunter-gatherer societies in certain parts of the Trans-Mississippi South (see Saunders 2010; Saunders et al. 1997; Saunders and Allen 1997). Such cultural developments apparently did not occur in East Texas.

\section{ACKNOWLEDGMENTS}

I thank Lance Trask for preparing all of the maps, figures, and photographs used in this article. I also thank Patti Haskins of the Gregg County Historical Museum for permission to study these projectile points in the Buddy Jones collection. Don G. Wyckoff graciously reviewed the projectile point images and provided his thoughts and impressions about the points and their raw materials.

\section{REFERENCES CITED}

Anderson, D. G.

1996a Models of Paleoindian and Early Archaic Settlement in the Lower Southeast. In The Paleoindian and Early Archaic Southeast, edited by D. G. Anderson and K. E. Sassaman, pp. 29-57. University of Alabama Press, Tuscaloosa.

1996b Approaches to Modeling Regional Settlement in the Archaic Period Southeast. In The Archaeology of the Mid-Holocene Southeast, edited by K. E. Sassaman and D. G. Anderson, pp. 157-176. University Press of Florida, Gainesville. 
Anderson, D. G. and S. D. Smith

2003 Archaeology, History, and Predictive Modeling: Research at Fort Polk, 1972-2002. University of Alabama Press, Tuscaloosa.

Banks, L. D.

1990 From Mountain Peaks to Alligator Stomachs: A Review of Lithic Sources in the Trans-Mississippi South, the Southern Plains, and Adjacent Southwest. Memoir \#4. Oklahoma Anthropological Society, Norman.

Bousman, C. B. and E. Oksanen

2012 The Protoarchaic in Central Texas and Surrounding Areas. In From the Pleistocene to the Holocene: Human Organization and Cultural Transformations in Prehistoric North America, edited by C. B. Bousman and B. J. Vierra, pp. 197-232. Texas A\&M University Press, College Station.

Bousman, C. B., M. B. Collins, P. Goldberg, T. Stafford, J. Guy, B. W. Baker, D. G. Steele, M. Kay, A. Kerr, G. Fredlund, P. Dering, V. Holliday, D. Wilson, W. Gose, S. Dial, P. Takac, R. Balinksy, M. Masson, and J. F. Powell

2002 The Palaeoindian-Archaic transition in North America: new evidence from Texas. Antiquity 76:980990.

Carpenter, S. and P. Paquin

2010 Towards a Genealogy of Texas Stone Projectile Points. Bulletin of the Texas Archeological Society 81:153-175.

Cliff, M. B., M. M. Green, S. M. Hunt, D. Shanabrook, and D. E. Peter

1996 Excavations at 41CS151, Area C, White Oak Creek Mitigation Area (WOCMA), Cass County, Texas. White Oak Creek Mitigation Area Archeological Technical Series, Report of Investigations, Number 4. Geo-Marine, Inc., Plano.

Collins, M. B. (assembler and editor)

1998 Wilson-Leonard: An 11,000-year Archeological Record of Hunter-Gatherers in Central Texas, Volume I: Introduction, Background, and Synthesis. Studies in Archeology 31, Texas Archeological Research Laboratory, The University of Texas at Austin, and Archeology Studies Program, Report 10, Texas Department of Transportation, Environmental Affairs Division, Austin.

Collins, M. B., D. M. Yelacic, and C. B. Bousman

2011 "Realms," A Look at Paleoclimate and Projectile Points in Texas. Bulletin of the Texas Archeological Society 82:3-30.

Fields, R. C., M. E. Blake, and K. W. Kibler

1997 Synthesis of the Prehistoric and Historic Archeology of Cooper Lake, Delta and Hopkins Counties, Texas. Reports of Investigations No. 104. Prewitt \& Associates, Inc., Austin.

Furman, E. and C. Amick

2006 Archaeological Investigations at 41AN115. Journal of Northeast Texas Archaeology 21:15-63.

Girard. J. S.

2000 Regional Archeology Program Management Unit 1, Eleventh Annual Report. Northwestern State University of Louisiana, Natchitoches.

Girard, J. S., N. Heller, J. P. Dering, S. L. Scott, H. E. Jackson, and G. L. Stringer

2011 Investigations at the Conly Site, a Middle Archaic Period Settlement in Northwest Louisiana. Louisiana Archaeology 32:5-77.

Jennings, T. A.

2008a San Patrice Technology and Mobility across the Plains-Woodland Border. Memoir 12, Oklahoma Anthropological Society, and R. E. Bell Monographs in Anthropology No. 5, Sam Noble Oklahoma Museum of Natural History, University of Oklahoma, Norman. 
2008b San Patrice: An Example of Late Paleoindian Adaptive Versatility in South-Central North America. American Antiquity 73(3):539-559.

Johnson, L., Jr.

1989 Great Plains Interlopers in the Eastern Woodlands during Paleo-Indian Times. Report 36. Office of the State Archeologist, Texas Historical Commission, Austin.

Jones, B. C.

1957 The Grace Creek Sites, Gregg County, Texas. Bulletin of the Texas Archeological Society 28:198231.

Kay, M.

2012 The Ozark Highland Paleoarchaic. In From the Pleistocene to the Holocene: Human Organization and Cultural Transformations in Prehistoric North America, edited by C. B. Bousman and B. J. Vierra, pp. 233-251. Texas A\&M University Press, College Station.

Knudson, R.

2002 Medicine Creek Is a Paleoindian Cultural Ecotone: The Red Smoke Assemblage. In Medicine Creek: Seventy Years of Archaeological Investigations, edited by D. C. Roper, pp. 84-141. University of Alabama Press, Tuscaloosa.

2013 The Scottsbluff Bison Quarry Site: Its Place in the Cody Complex. In Paleoindain Lifeways of the Cody Complex, edited by E. J. Knell and M. P. Muniz, pp. 290-314. University of Utah Press, Salt Lake City.

Koldehoff, B. and J. A. Walthall

2009 Dalton and the Early Holocene Midcontinent: Setting the Stage. In Archaic Societies: Diversity and Complexity across the Midcontinent, edited by T. E. Emerson, D. L. McElrath, and A. C. Fortier, pp. 137-151. State University of New York Press, Albany.

Lipo, C. P., M. J. O’Brien, M. Collard, and S. J. Shennan (editors)

2006 Mapping Our Ancestors: Phylogenetic Approaches in Anthropology and Prehistory. AldineTransaction, New Brunswick, New Jersey.

O'Brien, M. J. and R. L. Lyman

2003 Cladistics and Archaeology. University of Utah Press, Salt Lake City.

Perttula, T. K. and B. Nelson

2006 Test Excavations at Three Caddo Sites at Mission Tejas State Park, Houston County, Texas. Report of Investigations No. 76. Archeological \& Environmental Consultants, LLC, Austin.

Ray, J. H. and N. H. Lopinot

2003 Middle Archaic Components and Chert Use at the Bass Site. Missouri Archaeological Society Quarterly 20(2):4-16.

Ray, J. H., N. H. Lopinot, and E. R. Hajic

2009 Archaic Prehistory of the Western Ozarks of Southwest Missouri. In Archaic Societies: Diversity and Complexity across the Midcontinent, edited by T. E. Emerson, D. L. McElrath, and A. C. Fortier, pp. 155-197. State University of New York Press, Albany.

Rees, M. A.

2010 Paleoindian and Early Archaic. In Archaeology of Louisiana, edited by M. A. Rees, pp. 34-62. Louisiana State University Press, Baton Rouge.

Rogers, R. and T. K. Perttula

2004 The Oak Hill Village Site (41RK214), Rusk County, Texas. Document No. 030083. PBS\&J, Austin.

Saunders, J.

2010 Middle Archaic and Watson Brake. In Archaeology of Louisiana, edited by M. A. Rees, pp. 63-77. Louisiana State University Press, Baton Rouge. 
Saunders, J. and T. Allen

1997 The Archaic Period. Louisiana Archaeology 22:1-30.

Saunders, J. W., R. D. Mandel, R. T. Saucier, E. T. Allen, C. T. Hallmark, J. K. Johnson, E. H. Jackson, C. M.

Allen, G. L. Stringer, D. S. Frink, J. K. Feathers, S. Williams, K. J. Gremillion, M. F. Vidrine, and R. Jones 1997 A Mound Complex in Louisiana at 5400-5000 Years Before the Present. Science 277:1796-1799.

Schambach, F. F.

1998 Pre-Caddoan Cultures in the Trans-Mississippi South: A Beginning Sequence. Research Series 53. Arkansas Archeological Survey, Fayetteville.

Story, D. A.

1990 Cultural History of the Native Americans. In The Archeology and Bioarcheology of the Gulf Coastal Plain, by D. A. Story, J. A. Guy, B. A. Burnett, M. D. Freeman, J. C. Rose, D. G. Steele, B. W. Olive, and K. J. Reinhard, pp. 163-366. 2 Vols. Research Series No. 38. Arkansas Archeological Survey, Fayetteville.

Thurmond, J. P.

1990 Archeology of the Cypress Creek Drainage Basin, Northeastern Texas and Northwestern Louisiana. Studies in Archeology 5. Texas Archeological Research Laboratory, The University of Texas at Austin.

Trubitt, M. B.

2009 Investigating Middle Archaic at the Jones Mill Site. The Arkansas Archeologist 48:71-84.

Turner, E. S., T. R. Hester, and R. L. McReynolds

2011 Stone Artifacts of Texas Indians. Third Edition. Taylor Trade Publishing, Lanham, Maryland.

Turner, R. L., Jr.

2006 Hematite Axes of Northeast Texas. Bulletin of the Texas Archeological Society 77:1-31.

Waters, M. R. and T. W. Stafford, Jr.

2007 Redefining the Age of Clovis: Implications for the Peopling of the Americas. Science 315:1122-1126.

Waters, M. R., C. D. Pevny, and D. L. Carlson

2011 Clovis Lithic Technology: Investigations of a Stratified Workshop at the Gault Site, Texas. Texas A\&M University Press, College Station.

Webb, C. H.

2000 Stone Points and Tools of Northwestern Louisiana. 2nd Edition. Special Publication No. 1. Louisiana Archaeological Society, Baton Rouge.

Webb, C. H., J. L. Shiner, and E. W. Roberts

1971 The John Pearce Site (16CD56): A San Patrice Site in Caddo Parish, Louisiana. Bulletin of the Texas Archeological Society 42:1-49. 